\title{
Uptake of Thyroxine in Cultured Anterior Pituitary Cells of Euthyroid Rats*
}

\author{
M. E. EVERTS $\dagger$, R. DOCTER, E. P. C. M. MOERINGS, P. M. van KOETSVELD, T. J. VISSER, \\ M. DE JONG, E. P. KRENNING, AND G. HENNEMANN \\ Departments of Internal and Nuclear Medicine, Erasmus University Medical School, 3000 DR Rotterdam, \\ The Netherlands
}

\begin{abstract}
The uptake of $\left.{ }^{125} \mathrm{I}\right] \mathrm{T}_{4}$ was investigated in cultured anterior pituitary cells isolated from adult fed Wistar rats and cultured for 3 days in medium containing $10 \%$ fetal calf serum. Experiments were performed with $\left[{ }^{125} \mathrm{I}\right] \mathrm{T}_{4}\left(10^{5}\right.$ to $\left.2 \times 10^{6} \mathrm{cpm} ; 0.35-7 \mathrm{nM}\right)$ in medium containing $0.5 \%$ or $0.1 \%$ BSA. The uptake of $\left[{ }^{125}{ }^{1}\right] \mathrm{T}_{4}$ increased with time and showed equilibrium after around $1 \mathrm{~h}$ of incubation. The presence of 10 $\mu \mathrm{M}$ unlabeled $\mathrm{T}_{4}$ during incubation decreased the uptake of $\left[{ }^{125} \mathrm{I}\right] \mathrm{T}_{4}$ by $65-70 \%$ at all time intervals. After $24 \mathrm{~h}$ of incubation, $1.5 \%$ iodide and $3.2 \%$ conjugates were detected in the medium, whereas around $20 \%$ of cellular radioactivity represented $\left[{ }^{125} \mathrm{I}\right] \mathrm{T}_{3}$. The 15 -min uptake of $\left[{ }^{125} \mathrm{I}\right]$ $\mathrm{T}_{4}$ was significantly reduced by simultaneous incubation with $100 \mathrm{nM}$ $\mathrm{T}_{4}$ (by $24 \% ; P<0.05$ ), $100 \mathrm{nM} \mathrm{T}$ (by $38 \% ; P<0.001$ ), or $10 \mu \mathrm{M} \mathrm{rT}_{3}$ (by $32 \% ; P<0.001$ ), whereas $10 \mu \mathrm{M}$ tetraiodothyroacetic acid (Tetrac) had no effect. Furthermore, preincubation ( $30 \mathrm{~min}$ ) and incubation (15 min) with $10 \mu \mathrm{M}$ monodansylcadaverine, oligomycin, or monensin
\end{abstract}

reduced the uptake of $\left[{ }^{125} \mathrm{I}\right] \mathrm{T}_{4}$ by $30 \%, 50 \%$, and $40 \%$, respectively (all $P<0.001)$. Substitution of $\mathrm{Na}^{+}$in the buffer by $\mathrm{K}^{+}$diminished the uptake of $\left[{ }^{125} \mathrm{I}\right] \mathrm{T}_{4}$ by $39 \%(P<0.005) ; 2 \mathrm{mM}$ phenylalanine, tyrosine, or tryptophan reduced $\left[{ }^{125} \mathrm{I}\right] \mathrm{T}_{4}$ uptake by $18 \%(P<0.05), 18 \%(P=$ NS), and $33 \%(P<0.005)$, respectively. Our data suggest that the pituitary contains a specific carrier-mediated energy-requiring mechanism for $\left[{ }^{125} \mathrm{I}\right] \mathrm{T}_{4}$ uptake that is partly dependent on the $\mathrm{Na}^{+}$gradient. In addition, part of [ $\left.{ }^{125} I\right] \mathrm{T}_{4}$ uptake in the pituitary might occur through an amino acid transport system. When expressed per pM of free hormone, the 15 -min uptake of $\left[{ }^{125} \mathrm{I}\right] \mathrm{T}_{4}$ was approximately as high as that of $\left[{ }^{125} \mathrm{I}\right] \mathrm{T}_{3}$. Because the reduction of $\left[{ }^{125} \mathrm{I}\right] \mathrm{T}_{4}$ uptake by $\mathrm{T}_{4}, \mathrm{~T}_{3}$, monodansylcadaverine, oligomycin, and monensin was roughly the same as the previously reported reduction of $\left[{ }^{125} \mathrm{I}\right] \mathrm{T}_{3}$ uptake by the same compounds, it is further suggested that $\mathrm{T}_{4}$ and $\mathrm{T}_{3}$ share a common carrier in cultured anterior pituitary cells. (Endocrinology 134: 2490 2497, 1994)
$\mathrm{A}$ ROUND $50 \%$ of the intracellular available $T_{3}$ in the pituitary is derived from plasma $\mathrm{T}_{3}$, and around $50 \%$ is from intracellular $T_{4}$ to $T_{3}$ conversion $(1,2)$. During starvation in rats, plasma $T_{4}$ and $T_{3}$ are decreased, and the $T_{4}$ to $\mathrm{T}_{3}$ converting activity in the pituitary is reduced (3). Nevertheless, nuclear $T_{3}$ is maintained at a normal level in the pituitary of the fasted animal (3), and the plasma level of TSH is not increased (4) or may even decline (3). Although diminished release of TRH at least partly may explain the low TSH level during food deprivation in rats $(4,5)$, the observations of St. Germain and Galton (3) suggest that the suppression of TSH secretion during starvation could also be mediated by local pituitary mechanisms, i.e. active uptake of $\mathrm{T}_{3}$ and/or $\mathrm{T}_{4}$ to maintain normal nuclear receptor occupancy.

The early studies of Horiuchi et al. (6) and Halpern and Hinkle (7) and the recent study of Yan and Hinkle (8) demonstrated that $T_{3}$ is taken up by a carrier-mediated process in pituitary tumor cells. In cultured anterior pituitary cells of euthyroid rats, the uptake of $\left[{ }^{125} \mathrm{I}\right] \mathrm{T}_{3}$ was found to be carrier mediated and dependent on the cellular energy status and the transmembrane $\mathrm{Na}^{+}$gradient (9).

The purpose of the present study was to investigate

Received November 17, 1993.

Address all correspondence and requests for reprints to: Dr. M. E. Everts, Department of Internal Medicine III, Erasmus University Medical School, P.O. Box 1738, NL-3000 DR Rotterdam, The Netherlands.

* This work was supported by the Trustfonds of the Erasmus University Rotterdam (The Netherlands).

t Recipient of a fellowship from the Royal Netherlands Academy of Arts and Sciences. whether a comparable transport system exists for $T_{4}$ in the normal anterior pituitary gland. Apart from hepatocytes isolated from rats $(10)$ or trout (11), the uptake of $\mathrm{T}_{4}$ was previously shown to be saturable and energy dependent in rat glial cells in primary culture (12), in a mouse neuroblastoma cell line (13), as well as in pituitary tumor cells (8). Furthermore, in the mouse neuroblastoma cell line (13), cultured astrocytes (14), as well as pituitary tumor cells (8), the transport of $\mathrm{T}_{3}$ and $\mathrm{T}_{4}$ was competitively inhibited by amino acids transported by system $L$. On the other hand, in erythrocytes, the uptake of $\mathrm{T}_{3}$ was competitively inhibited by amino acids transported by system $T$ (15). Both systems $\mathrm{L}$ and $\mathrm{T}$ are independent of the $\mathrm{Na}^{+}$gradient, and both systems transport the aromatic amino acids (16).

Experiments were performed with primary cultures of anterior pituitary cells of euthyroid rats (9). The uptake of $T_{4}$ was characterized by testing the time and energy dependence; the specificity of inhibition by $T_{4}, T_{3}, r_{3}$, and Tetrac; the dependence on the $\mathrm{Na}^{+}$gradient; and the effect of the aromatic amino acids phenylalanine, tyrosine, and tryptophan.

\section{Materials and Methods}

\section{Materials}

All solutions used for cell isolation and cell culture were obtained from GIBCO Europe (Breda, The Netherlands), with the exception of human serum albumin (Central Laboratory of the Red Cross Blood Transfusion Service, Amsterdam, The Netherlands), dispase (grade II; Boehringer, Mannheim, Germany), and Fungizone (Bristol-Myers 
Squibb, Woerden, The Netherlands). Culture dishes (48 wells) were purchased from Costar (Cambridge, MA). $\mathrm{L}^{-} \mathrm{T}_{3}, \mathrm{~L}-\mathrm{T}_{4}, \mathrm{rT}_{3}$, tetraiodothyroacetic acid (Tetrac), piperazine- $N, N^{\prime}$-bis-[2-ethane sulfonic acid] (PIPES), HEPES, N,N-bis-[2-hydroxyethyl]2-aminoethane sulfonic acid (Bes), BSA (fraction V), monensin, monodansylcadaverine (MDC), oligomycin, L-phenylalanine (L-Phe), L-tyrosine ( $\mathrm{L}-\mathrm{Tyr}$ ), L-tryptophan (LTrp), and bromodeoxyuridine (BrdU) were purchased from Sigma (St. Louis, MO). $\left[3^{\prime}, 5^{\prime}-125 \mathrm{I}\right] \mathrm{T}_{4}(1500 \mu \mathrm{Ci} / \mu \mathrm{g})$ and $\left[3^{\prime}-{ }^{125} \mathrm{I}\right] \mathrm{T}_{3}(3070 \mu \mathrm{Ci} / \mu \mathrm{g})$ were purchased from Amersham International (Aylesbury, United Kingdom). Sephadex LH-20 was obtained from Pharmacia (Uppsala, Sweden). All other reagents were of the highest purity available.

\section{Animals}

All experiments were performed using male Wistar rats, weighing 220-250 g. The animals had free access to food and water and were kept in a controlled environment $(21 \mathrm{C})$ with constant day length (12 h).

\section{Cell culture}

Animals ( 12 for each experiment) were killed between $0900-0930 \mathrm{~h}$ by decapitation. The pituitary glands were removed within $5 \mathrm{~min}$, the neurointermediate lobe was discarded, and the anterior lobes were collected in calcium- and magnesium-free Hanks' Balanced Salt Solution, supplemented with $10 \mathrm{~g} /$ liter human serum albumin, penicillin $\left(10^{5} \mathrm{U} /\right.$ liter), Fungizone $(0.5 \mathrm{mg} / \mathrm{hiter})$, and sodium bicarbonate $(0.4 \mathrm{~g} / \mathrm{liter})$. Anterior pituitary cells were dissociated with dispase (final concentration, $2.4 \times 10^{3} \mathrm{U} /$ liter), as described in detail previously (17). From each pituitary, 1-2 $\times 10^{6}$ cells were obtained, and the viability of the cells, determined by trypan blue exclusion, was greater than $90 \%$.

The cells were cultured at $37 \mathrm{C}$ in a water-jacketed incubator with $5 \% \mathrm{CO}_{2}$ at a density of 500,000 cells/well in 48 -well culture dishes. The cells had attached to the wells after 2 days of culture. On day 3 , the cells were used for experiments. The culture medium consisted of Minimum Essential Medium with Earle's salts (MEM) supplemented with nonessential amino acids, sodium pyruvate $(1 \mathrm{mmol} / \mathrm{liter}), 10 \%$ fetal calf serum, penicillin ( $\left.10^{5} \mathrm{U} / \mathrm{liter}\right)$, Fungizone $(0.5 \mathrm{mg} / \mathrm{liter})$, $\mathrm{L}-$ glutamine ( $2 \mathrm{mmol} / \mathrm{liter}$ ), and sodium bicarbonate ( $2.2 \mathrm{~g} /$ liter; $\mathrm{pH} 7.4$ ) $(17,18)$.

In some experiments, the contamination of the pituitary cell preparation with fibroblasts was evaluated by adding $\operatorname{BrdU}(15 \mu \mathrm{g} / \mathrm{ml})$ to the cell culture (19) or by replacing L-valine (L-Val) with $\mathrm{D}$-Val in the culture medium $(20,21)$.

\section{Uptake of $\left[^{125} I\right] T_{4}$}

After removal of culture medium, cells were preincubated with 0.5 $\mathrm{ml}$ incubation medium. The incubation medium was identical to the culture medium, except that the fetal calf serum was replaced by 0.1 or $0.5 \%$ BSA. Preincubation was carried out at $37 \mathrm{C}$ for $30 \mathrm{~min}$ in the presence or absence of monensin $(10 \mu \mathrm{M}), \operatorname{MDC}(10$ or $25 \mu \mathrm{M})$, oligomycin $(10 \mu \mathrm{M})$, L-Phe ( $2 \mathrm{mM}), \mathrm{L}-\mathrm{Tyr}(2 \mathrm{mM})$, or L-Trp $(2 \mathrm{mM})$. After preincubation, the medium was removed, and incubation was started with $0.25 \mathrm{ml}$ medium containing the same additions as described above or $T_{4}, T_{3}, \mathrm{rT}_{3}$, or Tetrac $(10 \mathrm{nM}$ to $10 \mu \mathrm{M})$ and in all cases $\left[{ }^{12.5} \mathrm{I}\right] \mathrm{T}_{4}(100,000-200,000$ cpm; 350-700 pM). In one experiment lasting $24 \mathrm{~h}$, the cells were incubated with $\left.2 \times 10^{6} \mathrm{cpm} \mathrm{[}{ }^{125} \mathrm{I}\right] \mathrm{T}_{4}(7 \mathrm{nM})$ to allow analysis of the cellassociated radioactivity by Sephadex LH-20 chromatography and subsequently by HPLC.

Incubations lasting for more than $1 \mathrm{~h}$ were performed at $37 \mathrm{C}$ in humidified air with $5 \% \mathrm{CO}_{2}$. Incubations of shorter duration took place in a $37 \mathrm{C}$ incubation chamber on a rotating device without $\mathrm{CO}_{2}$. Therefore, the $\mathrm{NaHCO}_{3}$ in the culture medium was replaced by an equimolar amount of HEPES (8.9 mM), PIPES (10.6 mM), and Bes (11.2 mM).

After incubation, the medium was removed, and the cells were washed with $1-\mathrm{ml}$ volumes of ice-cold saline to remove tracer not bound to the cells. Cells were dissolved in $1 \mathrm{ml} 0.1 \mathrm{~N} \mathrm{NaOH}$ and counted for ${ }^{125}$ I activity in a 16-channel $\gamma$-counter (NE 1600, Nuclear Enterprises, Sighthill, Edinburgh, Scotland). The amount of $\left[{ }^{125} \mathrm{I}\right] \mathrm{T}_{4}$ taken up was expressed as a percentage of the radioactivity in the incubation medium (percent dose). The same procedure was applied to the incubations without cells. All results are corrected for the amount of radioactivity retained in the wells without cells.

To allow evaluation of the $\mathrm{Na}^{+}$dependence of the uptake of $\left[{ }^{125} \mathrm{IJT}_{4}\right.$, the cells were incubated in a Krebs-Ringer (KR) buffer containing 140 $\mathrm{mm} \mathrm{NaCl}, 4.2 \mathrm{~mm} \mathrm{KCl}, 1.5 \mathrm{mM} \mathrm{CaCl}_{2}, 1.4 \mathrm{~mm} \mathrm{KH}_{2} \mathrm{PO}_{4}, 1.4 \mathrm{mM} \mathrm{MgSO}_{4}$. $7 \mathrm{H}_{2} \mathrm{O}, 5 \mathrm{~mm}$ D-glucose, $25 \mathrm{~mm}$ Tris- $\mathrm{HCl}$, and $0.1 \%$ BSA (pH 7.4) or in $\mathrm{KR}$ buffer where $\mathrm{Na}^{+}$was replaced by $\mathrm{K}^{+}$or choline.

In some experiments, the uptake of $\left[{ }^{125} \mathrm{I}\right] \mathrm{T}_{3}$ was measured in medium containing $0.5 \% \mathrm{BSA}$, as previously described (9).

\section{Iodide production}

Aliquots of the incubation medium were chromatographed on Sephadex LH-20 (22). Iodide was eluted from the column with $4 \times 1 \mathrm{ml} 0.1$ $\mathrm{N} \mathrm{HCl}$. Subsequently, conjugates were eluted with $8 \times 1 \mathrm{ml} \mathrm{H}_{2} \mathrm{O}$; finally, the iodothyronines were removed from the column with $3 \times 1 \mathrm{ml}$ $\mathrm{NH}_{4} \mathrm{OH}$ in ethanol.

\section{$H P L C$}

Solvent ( $1 \% \mathrm{NH}_{4} \mathrm{OH}$ in ethanol) of samples prepurified on Sephadex LH-20 was evaporated under a stream of $\mathrm{N}_{2}$ at $50 \mathrm{C}$. The residue was redissolved in the HPLC mobile phase and injected onto Chromspher $\mathrm{C}_{18}$ columns (10 $\times 0.3 \mathrm{~cm}$; Chrompack International, Middelburg, The Netherlands) fitted in a Waters HPLC system (Waters Associates, Milford, MA). Isocratic elution was performed with a 50:50 mixture of methanol in $0.02 \mathrm{M}$ ammonium acetate $(\mathrm{pH} \mathrm{4})$ at a flow rate of $0.9 \mathrm{ml} /$ $\mathrm{min}$. Fractions of $0.3 \mathrm{~min}$ were collected and counted for radioactivity. Retention times of the unlabeled reference compounds were determined by monitoring the absorbance of the eluate at $254 \mathrm{~nm}$ (23).

\section{Free $T_{4}\left(F T_{4}\right)$ concentration}

Calculation of the $\mathrm{FT}_{4}$ concentration was based on determination of the free fraction by equilibrium dialysis (24). The incubation medium for the $\left[{ }^{125} \mathrm{I}\right] \mathrm{T}_{4}$ uptake experiments contained in the first experiments $0.5 \%$ BSA. However, as the $\mathrm{FT}_{4}$ fraction was only $0.41 \pm 0.03 \%(n=5)$ in medium with this protein concentration (Fig. 1), cellular uptake was low, and further experiments were performed with a reduced protein concentration in the incubation medium $(0.1 \% \mathrm{BSA})$, resulting in a $\mathrm{FT}_{4}$ fraction of $2.7 \pm 0.2 \%(n=8)$. With both $0.5 \%$ and $0.1 \%$ BSA in the incubation medium, the $\mathrm{FT}_{4}$ fraction increased substantially after the addition of $1 \mathrm{nM}$ to $10 \mu \mathrm{M}$ unlabeled $\mathrm{T}_{4}$ (Fig. 1). This was taken into account for calculation of the net cellular $\left[{ }^{125} \mathrm{I}\right] \mathrm{T}_{4}$ uptake by expressing the data per pM of $\mathrm{FT}_{4}$. The addition of monensin and oligomycin did not change the $\mathrm{FT}_{4}$ fraction, whereas 10 and $25 \mu \mathrm{M}$ MDC decreased the $\mathrm{FT}_{4}$ fraction by $12 \%$ and $21 \%$, respectively. A concentration of $2 \mathrm{~mm}$ of $\mathrm{L}-\mathrm{Phe}, \mathrm{L}-\mathrm{Tyr}$, and $\mathrm{L}$-Trp increased the $\mathrm{FT}_{4}$ fraction by $10 \%, 10 \%$, and $16 \%$, respectively.

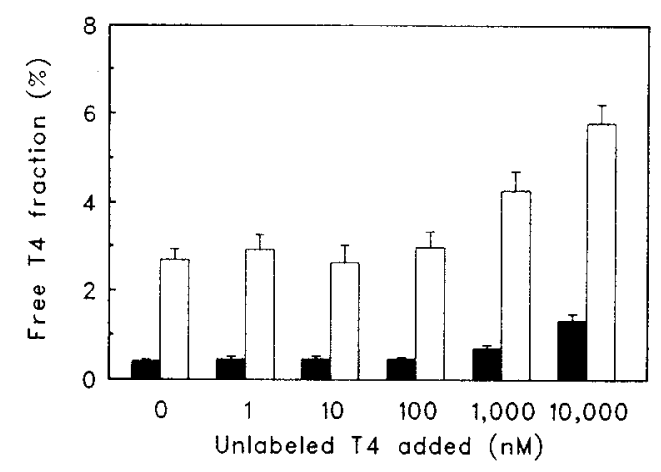

Fig. 1. The effect of addition of increasing concentrations of unlabeled $\mathrm{T}_{4}$ on the $\mathrm{FT}_{4}$ fraction in incubation medium with $0.5 \%$ (D) or $0.1 \%$ ( $\square$ ) BSA. Bars show the mean $\pm \mathrm{SE}$ of three to eight determinations of the $\mathrm{FT}_{4}$ fraction by equilibrium dialysis. 


\section{TSH determination}

TSH release was measured in the different culture media after 3 days of culture. TSH was determined by RIA, as previously described (9).

\section{DNA determination}

The DNA content of the wells after variation of the culture conditions was determined using a modification (25) of the fluorescence technique described by Downs and Wilfinger (26).

\section{Statistics}

The statistical significance of the effects of the various compounds on [ $\left.{ }^{125} \mathrm{I}\right] \mathrm{T}_{4}$ uptake was calculated using Student's $t$ test for unpaired observations. $P<0.05$ was regarded as statistically significant.

\section{Results}

Figure 2 shows the time course of the uptake of $\left[{ }^{125} \mathrm{I}_{\mathrm{T}}\right.$ by cultured anterior pituitary cells in incubation medium containing $0.5 \%$ BSA. $\left[{ }^{125} \mathrm{I}\right] \mathrm{T}_{4}$ uptake increased with time and reached equilibrium between $1-6 \mathrm{~h}$ of incubation (Fig. 2, upper curve). The presence of $10 \mu \mathrm{M}$ unlabeled $\mathrm{T}_{4}$ during incubation (Fig. 2, lower curve) decreased $\left[{ }^{125} \mathrm{~T}\right] \mathrm{T}_{4}$ uptake at all time intervals $(65-70 \%)$. By subtracting $\left[{ }^{125} \mathrm{I}\right] \mathrm{T}_{4}$ uptake in the presence of $10 \mu \mathrm{M} \mathrm{T} \mathrm{T}_{4}$ from uptake in the absence of unlabeled hormone, the curve for the saturable $\left[{ }^{125} \mathrm{I}\right] \mathrm{T}_{4}$ uptake was obtained, which clearly showed equilibrium after $1 \mathrm{~h}$ of incubation (Fig. 2, middle curve).

To see whether $\left[{ }^{125} \mathrm{I}\right] \mathrm{T}_{4}$ was metabolized in the cultured anterior pituitary cells, the incubation media from the experiment shown in Fig. 2 were analyzed by Sephadex LH-20 chromatography. Iodide production from $\left[{ }^{125} \mathrm{I}\right] \mathrm{T}_{4}$ increased roughly linearly with time and was at all time intervals completely blocked by the addition of $10 \mu \mathrm{M}$ unlabeled $\mathrm{T}_{4}$ (Table 1). The formation of conjugates also increased with time and was inhibited by the addition of unlabeled $T_{4}$,

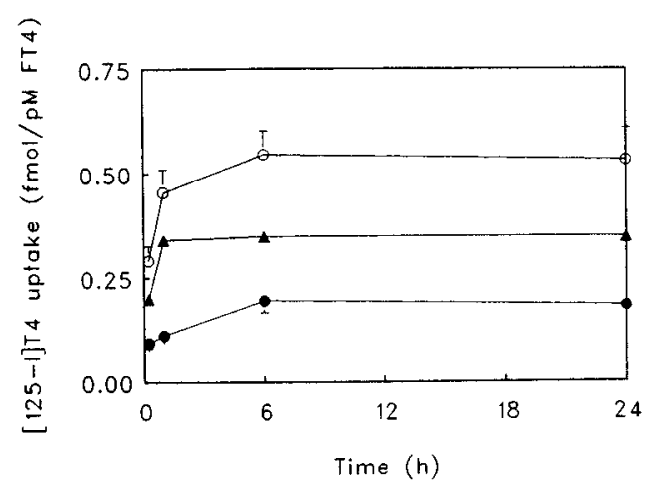

FIG. 2. Time course of $\left.{ }^{125} I\right] T_{4}$ uptake in the absence $(O)$ or presence (O) of $10 \mu \mathrm{M}$ unlabeled $\mathrm{T}_{4}$ in cultured anterior pituitary cells. The saturable component of $\left.{ }^{125} \mathrm{I}\right] \mathrm{T}_{4}$ uptake $(\boldsymbol{A})$ was calculated as the difference in the values in the absence and presence of $10 \mu \mathrm{M} \mathrm{T}$. Cells were cultured for 3 days at a density of 500,000 cells/well. After removal of the culture medium, the cells were preincubated for $30 \mathrm{~min}$ in incubation medium containing $0.5 \%$ BSA. Thereafter, they were incubated in the same medium for periods varying between $15 \mathrm{~min}$ and 24 $h$ with $\left.{ }^{125} \mathrm{I}\right] \mathrm{T}_{4}(200,000 \mathrm{cpm})$ without or with $10 \mu \mathrm{M}$ unlabeled $\mathrm{T}_{4}$, as described in Materials and Methods. Data represent the mean \pm SE of triplicate observations obtained in a single experiment.
TABLE 1. Time course of iodide production and conjugate formation from $\left[{ }^{125} \mathrm{I}\right] \mathrm{T}_{4}$ in cultured anterior pituitary cells

\begin{tabular}{ccc}
\hline $\begin{array}{c}\text { Experimental } \\
\text { conditions }\end{array}$ & $\begin{array}{c}\text { Iodide production } \\
(\%)\end{array}$ & $\begin{array}{c}\text { Conjugate formation } \\
(\%)\end{array}$ \\
\hline 15 min & & \\
No additions & $0.06 \pm 0.10$ & $1.00 \pm 0.05$ \\
$+10 \mu \mathrm{M} \mathrm{T}_{4}$ & $0.00 \pm 0.08$ & $0.22 \pm 0.05^{a}$ \\
$1 \mathrm{~h}$ & & \\
$\quad$ No additions & $0.11 \pm 0.19$ & $1.04 \pm 0.16$ \\
$\quad+10 \mu \mathrm{M} \mathrm{T}_{4}$ & $0.00 \pm 0.09$ & $0.21 \pm 0.04^{a}$ \\
$6 \mathrm{~h}$ & & \\
No additions & $0.61 \pm 0.04$ & $1.67 \pm 0.36$ \\
$+10 \mu \mathrm{M} \mathrm{T}_{4}$ & $0.06 \pm 0.04^{a}$ & $0.61 \pm 0.02^{a}$ \\
$24 \mathrm{~h}$ & & \\
No additions & $1.48 \pm 0.13$ & $3.18 \pm 0.31$ \\
$+10 \mu \mathrm{M} \mathrm{T}_{4}$ & $0.13 \pm 0.08^{a}$ & $2.09 \pm 0.08^{a}$ \\
\hline
\end{tabular}

Data represent the mean \pm SE of three observations in a single experiment (same as Fig. 2). After incubation, the medium was removed and analyzed by Sephadex LH-20 chromatography.

${ }^{a} P<0.05$ or less, $10 \mu \mathrm{M} \mathrm{T} \mathrm{T}_{4}$ vs. no additions.

TABLE 2. Effects of $10 \mathrm{nM}$ unlabeled $\mathrm{T}_{3}$ and $\mathrm{T}_{4}$ on the uptake and metabolism of $\left[{ }^{125} \mathrm{I}\right] \mathrm{T}_{4}$ in cultured anterior pituitary cells

\begin{tabular}{llcl}
\hline \multirow{2}{*}{$\begin{array}{c}\text { Experimental } \\
\text { conditions }\end{array}$} & $\begin{array}{c}\left.{ }^{125} \mathrm{f}\right] \mathrm{T}_{4} \text { uptake } \\
(\% \text { dose })\end{array}$ & \multicolumn{2}{c}{ Cellular content } \\
\cline { 3 - 4 } & & {$\left[{ }^{125} \mathrm{l}\right] \mathrm{T}_{3}(\%)$} & {$\left[{ }^{125} \mathrm{I}\right] \mathrm{T}_{4}(\%)$} \\
\hline No additions & $0.23 \pm 0.01$ & $21.5 \pm 1.5$ & $71.8 \pm 1.0$ \\
$+10 \mathrm{nM} \mathrm{T}_{3}$ & 0.12 & 8.4 & 81.9 \\
$+10 \mathrm{nM} \mathrm{T}_{4}$ & $0.12 \pm 0.01^{a}$ & $11.2 \pm 0.1^{a}$ & $81.6 \pm 0.6^{a}$ \\
\hline
\end{tabular}

Data indicate mean of two or mean \pm SE of three observations in a single experiment. Anterior pituitary cells were cultured for 3 days at a density of 500,000 cells/well. The cells were preincubated for $30 \mathrm{~min}$ and then incubated for $24 \mathrm{~h}$ with $\left[{ }^{125} \mathrm{I}_{\mathrm{T}}\left(2 \times 10^{6} \mathrm{cpm}\right)\right.$ in buffer containing $0.5 \%$ BSA in the absence or presence of $10 \mathrm{nM} \mathrm{T}_{3}$ or $\mathrm{T}_{4}$. Cell-associated radioactivity was analyzed by successive chromatography on Sephadex LH-20 and HPLC.

${ }^{a} P<0.001$ vs. no additions.

although to a smaller extent than the production of iodide (Table 1).

In a second experiment of this type, it was further investigated whether the uptake of $\left[{ }^{125} 1\right] \mathrm{T}_{4}$ into pituitary cells resulted in detectable $\left[{ }^{125} \mathrm{I}\right] \mathrm{T}_{3}$ formation. The results shown in Table 2 indicate that after $24 \mathrm{~h}$ of incubation, around $20 \%$ of the cell-associated radioactivity represented $\left[{ }^{125} \mathrm{I}\right] \mathrm{T}_{3}$. Furthermore, it can be seen from Table 2 that both the uptake and conversion of $\left[{ }^{125} \mathrm{I}\right] \mathrm{T}_{4}$ were reduced to the same extent $(\sim 50 \%)$ by simultaneous incubation with $10 \mathrm{nM} \mathrm{T}_{3}$ or $\mathrm{T}_{4}$.

To study the uptake of $\left[{ }^{125} \mathrm{I}\right] \mathrm{T}_{4}$ at the level of the pituitary plasma membrane, further experiments were performed with a short incubation time $(15 \mathrm{~min})(9)$. To increase the $\mathrm{FT}_{4}$ fraction and, thus, $\mathrm{T}_{4}$ availability to the cells, the protein concentration of the incubation medium was reduced to $0.1 \%$ BSA. In two experiments, the effect of decreasing the BSA concentration on $15-\min \left[{ }^{125}{ }^{125} \mathrm{~T}_{4}\right.$ uptake was tested. With $0.5 \%$ BSA in the medium, $\left[{ }^{125} \mathrm{IT}_{4}\right.$ uptake, expressed as a percentage of the dose, was $0.15 \pm 0.03(n=9)$; with $0.1 \%$ BSA, [ ${ }^{125} \mathrm{I}_{4}$ uptake was $0.50 \pm 0.04(\mathrm{n}=9 ; \mathrm{P}<0.001) .\left[{ }^{125} \mathrm{I}\right]$ $\mathrm{T}_{4}$ uptake, expressed as femtomoles per pM $\mathrm{FT}_{4}$, amounted to $0.087 \pm 0.017(n=9)$ with $0.5 \%$ BSA and $0.045 \pm 0.004$ $(n=9)(P<0.05)$ with $0.1 \%$ BSA in the medium.

Figure 3 shows the effect of increasing concentrations unlabeled $\mathrm{T}_{4}(10 \mathrm{nM}$ to $10 \mu \mathrm{M})$ on the 15 -min uptake of $\left[{ }^{125} \mathrm{I}\right]$ 


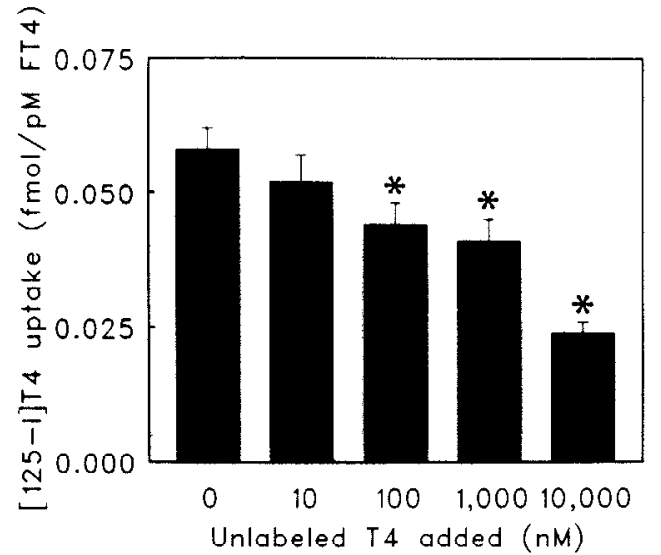

Fig. 3. Effects of increasing concentrations unlabeled $\mathrm{T}_{4}$ on $\left[{ }^{125} \mathrm{I}\right] \mathrm{T}_{4}$ uptake in cultured anterior pituitary cells. Cells were cultured for 3 days at a density of 500,000 cells/well, and the experiment was performed for $15 \mathrm{~min}$ in buffer containing $0.1 \% \mathrm{BSA}$, as described in Materials and Methods. Unlabeled $\mathrm{T}_{4}$ was added simultaneously with $\left[{ }^{125} \mathrm{I}\right] \mathrm{T}_{4}(100,000 \mathrm{cpm})$. Data represent the mean $\pm \mathrm{SE}$ of six to nine observations obtained in two experiments. ${ }^{*}, P<0.05$ or less, unlabeled $\mathrm{T}_{4}$ us. controls (left bar).

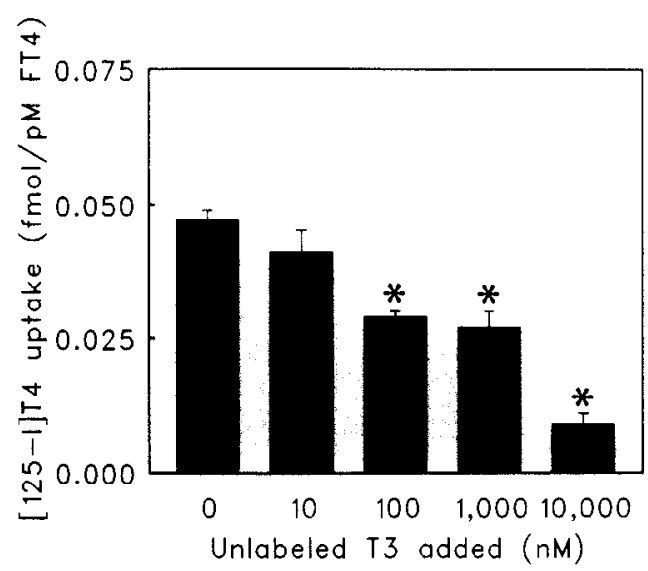

FIG. 4. Effects of increasing concentrations of unlabeled $\mathrm{T}_{3}$ on $\left[{ }^{125} I\right] \mathrm{T}_{4}$ uptake in cultured anterior pituitary cells. Cells were cultured for 3 days at a density of 500,000 cells/well, and the experiment was performed for $15 \mathrm{~min}$ in buffer containing $0.1 \% \mathrm{BSA}$, as described in Materials and Methods. Unlabeled $\mathrm{T}_{3}$ was added simultaneously with ${ }^{125} \mathrm{I}_{\mathrm{T}} \mathrm{T}_{4}(100,000 \mathrm{cpm})$. Data represent the mean $\pm \mathrm{SE}$ of six observations obtained in two experiments. ${ }^{*}, P<0.001$, unlabeled $\mathrm{T}_{3}$ vs. controls (left bar).

$\mathrm{T}_{4}$ in medium containing $0.1 \%$ BSA. Reduction of the uptake of ${ }^{125} \mathrm{IT}_{4}$ was already observed after the addition of $10 \mathrm{nM}$ unlabeled $\mathrm{T}_{4}(10 \%)$, and there was a significant reduction at $100 \mathrm{nM} \mathrm{T}_{4}(24 \% ; P<0.05)$. The maximum effect $(59 \% ; P<$ 0.001 ) was observed with $10 \mu \mathrm{M} \mathrm{T}_{4}$. When $\left[{ }^{125} \mathrm{I}\right] \mathrm{T}_{4}$ uptake was measured in the presence of unlabeled $\mathrm{T}_{3}(10 \mathrm{nM}$ to 10 $\mu \mathrm{M})$, a significant inhibition $(38 \% ; P<0.001)$ was observed with $100 \mathrm{nM} \mathrm{T}_{3}$, whereas the maximum effect $(63 \% ; P<$ 0.001 ) was obtained with a $T_{3}$ concentration of $10 \mu \mathrm{M}$ (Fig. $4)$.

The ability of $\mathrm{rT}_{3}$ and Tetrac to compete with the uptake of $\left[{ }^{125} \mathrm{I}\right] \mathrm{T}_{4}$ in cultured anterior pituitary cells was examined in a separate series of experiments. The results are shown in Table 3. $\mathrm{rT}_{3}$ at a concentration of $10 \mu \mathrm{M}$ reduced the uptake
TABLE 3. The effects of $\mathrm{rT}_{3}$ and Tetrac on the 15-min uptake of $\left[{ }^{125} \mathrm{I}\right] \mathrm{T}_{4}$ by cultured anterior pituitary cells

\begin{tabular}{lccc}
\hline $\begin{array}{c}\text { Experimental } \\
\text { conditions }\end{array}$ & $\begin{array}{c}{\left[{ }^{125}\left[\mathrm{~T}_{4} \text { uptake }\right.\right.} \\
(\% \text { dose })\end{array}$ & $\begin{array}{c}\mathrm{FT}_{4} \text { fraction } \\
(\%)\end{array}$ & $\begin{array}{c}{\left[{ }^{125}\right] \mathrm{T}_{4} \text { uptake }} \\
\left(\mathrm{fmol} / \mathrm{pM} \mathrm{FT}_{4}\right)\end{array}$ \\
\hline No additions & $0.54 \pm 0.02(9)$ & 3.4 & $0.040 \pm 0.001$ \\
$+10 \mu \mathrm{M} \mathrm{rT} \mathrm{T}_{3}$ & $0.65 \pm 0.03(6)$ & 6.1 & $0.027 \pm 0.001^{a}$ \\
$+10 \mathrm{nM}$ Tetrac & $0.58 \pm 0.05(3)$ & 3.5 & $0.041 \pm 0.003$ \\
$+10 \mu \mathrm{M}$ Tetrac & $1.20 \pm 0.04(6)$ & 7.8 & $0.038 \pm 0.001$ \\
\hline
\end{tabular}

Data represent the mean $\pm \mathrm{SE}$ of three to nine observations obtained in two independent experiments. Anterior pituitary cells were cultured for 3 days at a density of 500,000 cells/well. After preincubation for 30 min in buffer containing $0.1 \% \mathrm{BSA},\left[{ }^{125} \mathrm{I}\right] \mathrm{T}_{4}$ uptake was measured in the same buffer with $\left[{ }^{125} \mathrm{I}\right] \mathrm{T}_{4}(100,000 \mathrm{cpm})$ without or with the additions indicated.

${ }^{a} P<0.001$ us. no additions.

TABLE 4. Effects of $T_{4}, T_{3}$, and various compounds on the 15-min uptake of $\left[{ }^{125} \mathrm{I}\right] \mathrm{T}_{4}$ in cultured anterior pituitary cells

\begin{tabular}{|c|c|c|c|}
\hline $\begin{array}{l}\text { Experimental } \\
\text { conditions }\end{array}$ & $\begin{array}{l}{\left[{ }^{125} \mathrm{I}\right] \mathrm{T}_{4} \text { uptake }} \\
\left(\mathrm{fmol} / \mathrm{pM} \mathrm{FT}_{4}\right)\end{array}$ & $\begin{array}{c}\text { Effect } \\
(\%)\end{array}$ & $P$ \\
\hline $\begin{array}{l}\text { No additions } \\
+10 \mu \mathrm{M} \mathrm{T}_{4} \\
+10 \mu \mathrm{M} \mathrm{T}\end{array}$ & $\begin{array}{l}0.060 \pm 0.002(21) \\
0.029 \pm 0.003(9) \\
0.022 \pm 0.001(6)\end{array}$ & $\begin{array}{l}-52 \\
-63\end{array}$ & $\begin{array}{l}<0.001 \\
<0.001\end{array}$ \\
\hline $\begin{array}{l}+10 \mu \mathrm{M} \text { MDC } \\
+25 \mu \mathrm{M} \text { MDC }\end{array}$ & $\begin{array}{l}0.042 \pm 0.003(9) \\
0.039 \pm 0.001(9)\end{array}$ & $\begin{array}{l}-30 \\
-35\end{array}$ & $\begin{array}{l}<0.001 \\
<0.001\end{array}$ \\
\hline $\begin{array}{l}+10 \mu \mathrm{M} \text { oligomycin } \\
+10 \mu \mathrm{M} \text { monensin }\end{array}$ & $\begin{array}{l}0.030 \pm 0.005(9) \\
0.036 \pm 0.003(12)\end{array}$ & $\begin{array}{l}-50 \\
-40\end{array}$ & $\begin{array}{l}<0.001 \\
<0.001\end{array}$ \\
\hline
\end{tabular}

Data indicate the mean $\pm \mathrm{SE}$ of 6-21 observations. Each experiment was performed in triplicate and included at least one set of controls and two to four of the other additions. Anterior pituitary cells were cultured for 3 days at a density of around 500,000 cell/well. Experiments were performed in buffer containing $0.1 \%$ BSA. The cells were preincubated for $30 \mathrm{~min}$ in the absence or presence of MDC $(10$ or $25 \mu \mathrm{M})$, oligomycin $(10 \mu \mathrm{M})$, or monensin $(10 \mu \mathrm{M})$. Thereafter, they were incubated for $15 \mathrm{~min}$ with $\left[{ }^{125} \mathrm{I}\right] \mathrm{T}_{4}(100,000 \mathrm{cpm})$, as described in Materials and Methods, without or with the additions indicated.

of $\left[{ }^{125} \mathrm{IT}_{4}\right.$ by $32 \%(P<0.001)$. Up to $10 \mu \mathrm{M}$ Tetrac had no significant inhibitory effect on the uptake of $\left[{ }^{125} \mathrm{I}\right] \mathrm{T}_{4}$.

In a previous study it was found that the uptake of $\left[{ }^{125} \mathrm{I}\right]$ $\mathrm{T}_{3}$ by cultured anterior pituitary cells was reduced by MDC, oligomycin, and monensin (9). These substances were also tested with respect to their effects on $\left[{ }^{125} \mathrm{I}\right] \mathrm{T}_{4}$ uptake. The results are shown in Table 4 . The 15 -min uptake of $\left[{ }^{125} \mathrm{I}^{\mathrm{T}} \mathrm{T}_{4}\right.$ amounted to $0.060 \mathrm{fmol} / \mathrm{pM} \mathrm{FT}_{4}$. When MDC, an inhibitor of receptor-mediated endocytosis, was present at concentrations of 10 or $25 \mu \mathrm{M}$ during preincubation and incubation, the uptake of $\left[{ }^{125} \mathrm{I}^{\mathrm{T}} \mathrm{T}_{4}\right.$ was reduced by $30 \%(P<0.001)$ and $35 \%(P<0.001)$, respectively. Preincubation and incubation with oligomycin $(10 \mu \mathrm{M})$ reduced the uptake of $\left[{ }^{125} \mathrm{I}\right] \mathrm{T}_{4}$ by $50 \%(P<0.001)$, indicating energy dependence of the uptake process. Finally, $10 \mu \mathrm{M}$ monensin reduced the uptake of $\left[{ }^{125} \mathrm{I}\right]$ $\mathrm{T}_{4}$ by $40 \%(P<0.001)$, indicating the importance of the $\mathrm{Na}^{+}$ gradient.

Another approach to evaluate the $\mathrm{Na}^{+}$dependence of the $\left[{ }^{125} \mathrm{IJT}_{4}\right.$ uptake was to incubate the cultured anterior pituitary cells in buffer where $\mathrm{Na}^{+}$could be replaced by choline or $\mathrm{K}^{+}$. These effects could then be compared with the effects of $10 \mu \mathrm{M}$ monensin. The results of these experiments are shown in Table 5. It can be seen from Table 5, that the effect of 10 $\mu \mathrm{M}$ monensin in this type of buffer $(38 \% ; P<0.001)$ was the 
TABLE 5. $\mathrm{Na}^{+}$dependence of the 15 -min uptake of $\left[{ }^{125} \mathrm{I}\right] \mathrm{T}_{4}$ by cultured anterior pituitary cells

\begin{tabular}{lccc}
\hline $\begin{array}{c}\text { Experimental } \\
\text { conditions }\end{array}$ & $\begin{array}{c}\mathrm{I}^{125} \mathrm{I} \mathrm{T}_{4} \text { uptake } \\
(\% \text { dose })\end{array}$ & $\begin{array}{c}\text { Effect } \\
(\%)\end{array}$ & $P$ \\
\hline KR buffer & $1.15 \pm 0.08(9)$ & & \\
$+10 \mu \mathrm{M}$ monensin & $0.71 \pm 0.04(6)$ & -38 & $<0.001$ \\
$\mathrm{~K}^{+}-\mathrm{KR}$ buffer & $0.70 \pm 0.08(6)$ & -39 & $<0.005$ \\
Ch-KR buffer & $0.89 \pm 0.10(9)$ & -23 & $<0.1$ \\
\hline
\end{tabular}

Data indicate the mean \pm SE of six to nine observations obtained in two independent experiments. Anterior pituitary cells were cultured for 3 days at a density of around 500,000 cells/well. The cells were preincubated for $30 \mathrm{~min}$ in the absence or presence of $10 \mu \mathrm{M}$ monensin in Krebs-Ringer (KR) buffer with $0.1 \%$ BSA (see Materials and Methods). Thereafter, they were incubated for $15 \mathrm{~min}$ in the same buffer without or with monensin and $\left[{ }^{125} \mathrm{I}\right] \mathrm{T}_{4}(100,000 \mathrm{cpm})$. Cells were also preincubated and incubated in $\mathrm{KR}$ buffer, where $\mathrm{Na}^{+}$was replaced by $\mathrm{K}^{+}(\mathrm{K}-\mathrm{KR})$ or by choline (Ch-KR).

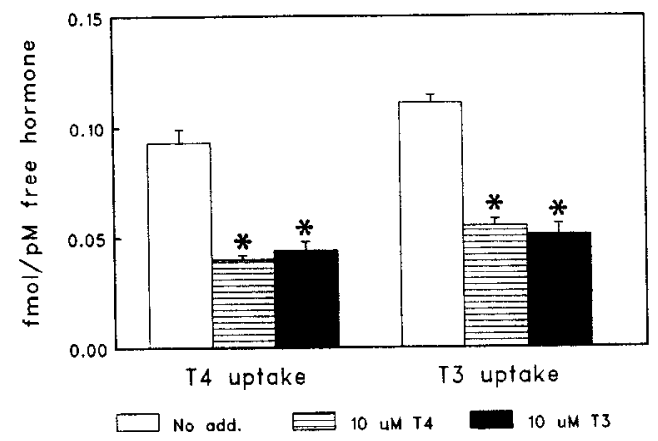

FIG. 5. The uptake of $\left[{ }^{125} \mathrm{I}\right] \mathrm{T}_{4}$ and $\left[{ }^{125} \mathrm{I}\right] \mathrm{T}_{3}$ and the effects of unlabeled $T_{4}$ and $T_{3}$ in cultured anterior pituitary cells of euthyroid rats. Cells were cultured for 3 days at a density of 500,000 cell/well. $\left[{ }^{125} \mathrm{IJT}_{4}\right.$ uptake was measured during $15 \mathrm{~min}$ in buffer containing $0.5 \% \mathrm{BSA}$, as described in Materials and Methods. Data for $\left[{ }^{125} \mathrm{I}\right] \mathrm{T}_{3}$ uptake are derived from Ref. 9 . ${ }^{*}, P<0.001$, unlabeled $\mathrm{T}_{4}$ or $\mathrm{T}_{3}$ us. no additions.

same as that observed in the usual buffer ( $40 \%$; see Table 3 ). Furthermore, replacing $\mathrm{Na}^{+}$in the buffer with $\mathrm{K}^{+}$or choline reduced the uptake of $\left[{ }^{125} \mathrm{I}\right] \mathrm{T}_{4}$ by $39 \%(P<0.005)$ and $23 \%$ $(0.05<P<0.1)$, respectively.

To directly compare $\left[{ }^{125} \mathrm{I}\right] \mathrm{T}_{4}$ and $\left[{ }^{125} \mathrm{I}\right] \mathrm{T}_{3}$ uptake by cultured anterior pituitary cells and the specificity of inhibition by unlabeled $\mathrm{T}_{4}$ and $\mathrm{T}_{3},\left[{ }^{125} \mathrm{I}\right] \mathrm{T}_{4}$ uptake was measured over 15 min in medium containing $0.5 \%$ BSA. The results are shown in Fig. 5, which also includes data from our previous study on $\left[{ }^{125} \mathrm{~T}\right] \mathrm{T}_{3}$ uptake (9). For both iodothyronines the uptake data were expressed per pM free hormone. It can be seen from Fig. 5 that the amount of hormone taken up in $15 \mathrm{~min}$ is the same for $\left[{ }^{225} I\right] \mathrm{T}_{4}$ and $\left[{ }^{125} I\right] \mathrm{T}_{3}$. The presence of equimolar concentrations of unlabeled $\mathrm{T}_{4}$ and $\mathrm{T}_{3}$ reduced $\left[{ }^{125} \mathrm{I}\right] \mathrm{T}_{4}$ uptake to the same extent (57\% and $53 \%$, respectively; both $P<$ $0.001)$, and vice versa, the uptake of $\left[{ }^{125} \mathrm{I}\right] \mathrm{T}_{3}$ was reduced to the same extent by $\mathrm{T}_{4}(50 \% ; P<0.001)$ and $\mathrm{T}_{3}(54 \% ; P<$ $0.001)$.

The possibility that thyroid hormones and amino acids might be transported into the cultured anterior pituitary cells through the same mechanism was also investigated. Therefore, the cells were preincubated and incubated with $2 \mathrm{~mm}$ L-Phe, L-Tyr, or L-Trp. The results are shown in Fig. 6. L-Phe had a small, but significant, inhibitory effect $(18 \% ; P<0.05)$ on the uptake of $\left[{ }^{125} \mathrm{I}\right] \mathrm{T}_{4}$, but not on the uptake of $\left[{ }^{125} \mathrm{I}\right] \mathrm{T}_{3}$.

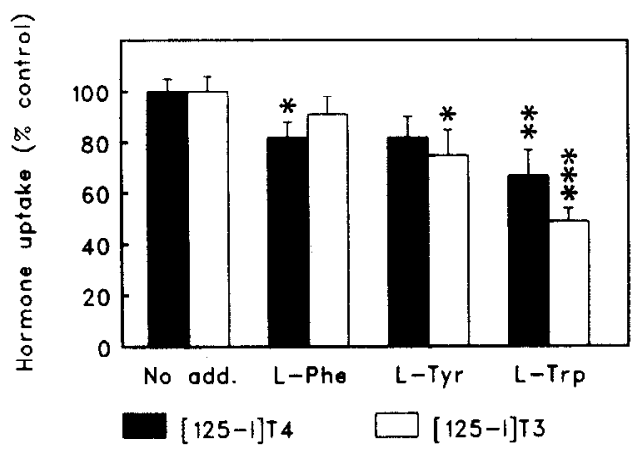

FIG. 6. Effects of aromatic amino acids on the 15-min uptake of $\left.{ }^{125} \mathrm{I}\right]$ $\mathrm{T}_{4}$ and $\left[{ }^{125} \mathrm{I}\right] \mathrm{T}_{3}$ in cultured anterior pituitary cells. Anterior pituitary cells were cultured for 3 days at a density of around 500,000 cells/well. $\left[{ }^{125} \mathrm{I}\right] \mathrm{T}_{4}$ uptake was measured in buffer containing $0.1 \% \mathrm{BSA}$, and $\left[{ }^{125} \mathrm{I}\right]$ $\mathrm{T}_{3}$ uptake was determined in buffer containing $0.5 \%$ BSA. The cells were preincubated for $30 \mathrm{~min}$ in the absence or presence of $2 \mathrm{mM} \mathrm{L}$ Phe, L-Tyr, or L-Trp, respectively. Thereafter, they were incubated for 15 min with $\left[{ }^{125} \mathrm{I}\right] \mathrm{T}_{4}(100,000 \mathrm{cpm})$ or $\left[{ }^{125} \mathrm{I}\right] \mathrm{T}_{3}(50,000 \mathrm{cpm})$, as described in Materials and Methods, without or with the additions indicated. Data represent the mean \pm SE of 6-18 observations obtained in 4 independent experiments. The results are expressed as a percentage of the control value (no additions). ${ }^{*}, P<0.05 ;^{* *}, P<0.005{ }^{* * *}, P<$ 0.001 ( $v s$. no additions).

The effect of L-Tyr on the uptake of $\left.{ }^{125}{ }^{12}\right] \mathrm{T}_{4}$ was as large as that of L-Phe, but not significant. On the other hand, L-Tyr reduced the uptake of $\left[{ }^{125} \mathrm{I}\right] \mathrm{T}_{3}$ by $25 \%(P<0.05)$. The presence of L-Trp reduced the uptake of both $\left[{ }^{125} \mathrm{IJT}_{4}(33 \%\right.$; $P<0.005)$ and $\left[{ }^{125} \mathrm{I}\right] \mathrm{T}_{3}(51 \% ; P<0.001)$. The effect of $\mathrm{L}-\mathrm{Trp}$ was further examined in experiments in which L-Trp was present during preincubation and incubation or only present during incubation. In two experiments of this type, it was observed that the effect of $L$-Trp on the uptake of $\left[{ }^{125} \mathrm{IT}_{3}\right.$ was just as large when the amino acid was present during incubation alone $(41 \% ; P<0.001)$ compared to its presence during both preincubation and incubation $(34 \% ; P<0.005$; not shown).

As primary tissue cultures may be contaminated with fibroblasts, and fibroblasts also show active transport of iodothyronines (27), we finally evaluated to what extent the presence of fibroblasts might contribute to the uptake of [ $\left.{ }^{125} \mathrm{I}\right]$ $\mathrm{T}_{3}$ and $\left[{ }^{125} \mathrm{~T}\right] \mathrm{T}_{4}$ by anterior pituitary cells in primary culture. For this purpose the cells were cultured in the normal culture medium in the absence or presence of $\mathrm{BrdU}(15 \mu \mathrm{g} / \mathrm{ml})$ or in a medium in which L-Val was replaced with $D$-Val. The results are shown in Table 6 . To assess the biological effects of this variation in culture conditions, TSH release was measured, whereas the effects on cell proliferation were examined by measuring the DNA content of the wells.

Both addition of $\mathrm{BrdU}$ and replacement of $\mathrm{L}-\mathrm{Val}$ with $\mathrm{D}$ Val reduced the uptake of $\left[{ }^{125} \mathrm{I}\right] \mathrm{T}_{3}$ and $\left[{ }^{125} \mathrm{I}\right] \mathrm{T}_{4}$ between 5 $20 \%$, suggesting that fibroblasts contribute little to the uptake of labeled iodothyronines by the cultured anterior pituitary cells. TSH release was not altered by the various culture conditions, suggesting an equal number of active thyrotrophs under the different conditions. Furthermore, the DNA content of the cells cultured with BrdU or D-Val was not reduced compared to that of cells cultured as usual. This indicated 
TABLE 6. Effects of culture conditions on the uptake of $\left[{ }^{125} \mathrm{I}\right] \mathrm{T}_{3}$,

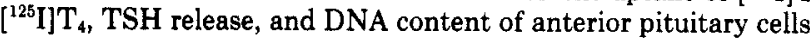

\begin{tabular}{|c|c|c|c|}
\hline $\begin{array}{l}\text { Parameter } \\
\text { measured }\end{array}$ & MEM-L-Val-FCS & $\begin{array}{c}\text { Culture conditions } \\
\text { MEM-L-Val-FCS } \\
+\mathrm{BrdU}(15 \mu \mathrm{g} / \\
\mathrm{ml})\end{array}$ & MEM-D-Val-FCS \\
\hline $\begin{array}{c}{\left[{ }^{125} \mathrm{I}\right] \mathrm{T}_{3} \text { uptake }} \\
(\% \text { dose })\end{array}$ & $1.34 \pm 0.08$ & $1.25 \pm 0.05(9)$ & $1.06 \pm 0.04(12)^{a}$ \\
\hline $\begin{array}{c}{\left[{ }^{125} \mathrm{I}\right] \mathrm{T}_{4} \text { uptake }} \\
\text { (\% dose })\end{array}$ & $0.37 \pm 0.02$ & $0.36 \pm 0.02(9)$ & $0.31 \pm 0.03(11)$ \\
\hline $\begin{array}{l}\text { TSH secretion } \\
\text { (ng/3 days) } \\
\text { DNA content } \\
(\mu \mathrm{g} / \text { well })\end{array}$ & $33.3 \pm 1.5(5)$ & $31.0 \pm 0.7(5)$ & $31.4 \pm 0.7(10)$ \\
\hline do & $3.00 \pm 0.11(4)$ & & $3.19 \pm 0.05(4)$ \\
\hline d3 & $2.26 \pm 0.06$ & $2.39 \pm 0.12$ & $2.55 \pm 0.05(6)^{b}$ \\
\hline
\end{tabular}

Data on the uptake of $\left[{ }^{125} \mathrm{I}\right] \mathrm{T}_{3}$ and $\left[{ }^{125} \mathrm{I}\right] \mathrm{T}_{4}$ indicate the mean $\pm \mathrm{SE}$ of four experiments, with the number of observations in parentheses. In one of these experiments, TSH was determined in the medium removed from the cells after 3 days of culture, whereas some of the plates were used for determination of the DNA content. Anterior pituitary cells were cultured for 3 days at a density of about 500,000 cells/well. After separation of the cells by dispase, two thirds of the cells were suspended in the normal culture medium (MEM-L-Val-FCS), and one third in culture medium in which $\mathrm{L}-\mathrm{Val}$ was replaced by $\mathrm{D}-\mathrm{Val}$ (MEM-D-Val-FCS). To half of the cells in normal culture medium, $\operatorname{BrdU}(15 \mu \mathrm{g} / \mathrm{ml})$ was added. The 15 -min uptake of $\left[{ }^{125} \mathrm{I}\right] \mathrm{T}_{3}(50,000$ cpm) was measured in buffer with $0.5 \% \mathrm{BSA}$, and that of $\left[{ }^{125} \mathrm{IlT}_{4}\right.$ $(100,000 \mathrm{cpm})$ was measured in buffer with $0.1 \%$ BSA. d0, Day $0 ; \mathrm{d} 3$, after 3 days of culture.

${ }^{a} P<0.005$ vs. MEM-L-Val-FCS.

${ }^{b} P<0.01$ us. MEM-L-Val-FCS.

that the presence of fibroblasts is only of minor importance in the short term primary culture of pituitary cells.

\section{Discussion}

The present study shows that the uptake of $\mathrm{T}_{4}$ into cultured anterior pituitary cells of euthyroid rats occurs by a transport system that is energy dependent and partly dependent on the $\mathrm{Na}^{+}$gradient. Our results are consistent with the possibility that $T_{4}$ is taken up by cultured anterior pituitary cells by the same transport system as $T_{3}$. In addition, our results suggest a relationship between the transport systems of iodothyronines and aromatic amino acids.

The peripheral effects of the thyroid hormones are primarily ascribed to the action of $T_{3}$, but $T_{4}$ is effective in suppressing pituitary TSH secretion in vivo, although to what extent this is due to a direct action of $\mathrm{T}_{4}$ or to intrapituitary conversion of $T_{4}$ has not been decided (28-31). We have recently shown that both $T_{3}$ and $T_{4}$ were capable of reducing TRH-induced TSH secretion in vitro, and that the uptake of $\mathrm{T}_{3}$ in cultured anterior pituitary cells occurred by a carriermediated mechanism (9). Therefore, it was important to investigate whether a comparable uptake system existed for $\mathrm{T}_{4}$ in these cells.

Whereas carrier-mediated uptake of $T_{3}$ has been demonstrated in a variety of tissues $(32,33)$, the evidence for an active transport system for $T_{4}$ is not as abundant (32). Apart from hepatocytes $(10,11)$, it has been described for a mouse neuroblastoma cell line (13), rat glial cells in primary culture
(12), and, very recently, pituitary tumor cells (8). The three last-mentioned cell types have in common that at least $50 \%$ of the nuclear bound $T_{3}$ is derived from intracellular $T_{4}$ to $T_{3}$ conversion (2).

The uptake of $\left[{ }^{125} \mathrm{I}\right] \mathrm{T}_{4}$ in cultured anterior pituitary cells showed roughly the same time dependence as the uptake of $\left[{ }^{125} \mathrm{I}\right] \mathrm{T}_{3}(9)$. That $\left[{ }^{125} \mathrm{I}\right] \mathrm{T}_{4}$ had indeed entered the pituitary cells was evident from significant iodide production, conjugate formation, and intracellular conversion of $T_{4}$ to $T_{3}$. Both the uptake and metabolism of $\left[{ }^{125} \mathrm{I}\right] \mathrm{T}_{4}$ were reduced to the same extent by incubation with a low concentration of unlabeled $\mathrm{T}_{3}$ or $\mathrm{T}_{4}$. Although the $50 \%$ reduction of $\left.{ }^{125} \mathrm{I}\right] \mathrm{T}_{3}$ formation in the cells in the presence of $10 \mathrm{nM} \mathrm{T}_{4}$ could be due to saturation of the type II deiodinase (34), the conversion of $\left[{ }^{125} \mathrm{I}\right] \mathrm{T}_{4}$ to $\left[{ }^{125} \mathrm{I}\right] \mathrm{T}_{3}$ was also reduced by $50 \%$ in the presence of $10 \mathrm{nM}$ $\mathrm{T}_{3}$. As $\mathrm{T}_{3}$ is not a substrate for the type II deiodinase, this could be due to reduced entry of $\left[{ }^{125} \mathrm{I}\right] \mathrm{T}_{4}$ or to a downregulation of the enzyme (35). At any rate, these results show that uptake and conversion of $\mathrm{T}_{4}$ in the cultured anterior pituitary cells are subject to regulation by thyroid hormone.

In line with our previous study on the uptake of $\left[{ }^{125} \mathrm{I}\right] \mathrm{T}_{3}$ in cultured anterior pituitary cells, the plasma membrane uptake of $\left[{ }^{125} \mathrm{I}\right] \mathrm{T}_{4}$ was examined in experiments with $15 \mathrm{~min}$ of incubation. The 15 -min uptake of $\left[{ }^{125}{ }^{1}\right] \mathrm{T}_{4}$ expressed per pM $\mathrm{FT}_{4}$ increased 2-fold when the albumin concentration in the medium was increased from $0.1 \%$ to $0.5 \%$ BSA. This was also observed with respect to $\mathrm{T}_{3}$ uptake in cultured hepatocytes (36). These researchers suggested that albumin is necessary for optimal diffusion through the unstirred water layer around the cells, and that increasing the concentration of albumin leads to augmentation of the processes involved in the transport and binding of $\mathrm{T}_{3}(36)$.

The 15-min uptake of $\left[{ }^{125} \mathrm{I}\right] \mathrm{T}_{4}$ was significantly reduced by unlabeled $\mathrm{T}_{4}$ at concentrations of $100 \mathrm{nM}$ or higher. Unlabeled $T_{3}$ reduced $\left[{ }^{125} \mathrm{I}\right] \mathrm{T}_{4}$ uptake to at least the same extent as unlabeled $\mathrm{T}_{4}$. On the other hand, $\mathrm{rT}_{3}$ at a concentration of $10 \mu \mathrm{M}$ had only a small effect, and Tetrac did not affect [ $\left.{ }^{125} \mathrm{I}\right]$ $\mathrm{T}_{4}$ uptake. Substances that previously were found to reduce $\left[{ }^{125} \mathrm{I}\right] \mathrm{T}_{3}$ uptake by cultured anterior pituitary cells were in the present study tested on $\left[{ }^{125} \mathrm{I}\right] \mathrm{T}_{4}$ uptake. MDC concentrations of 10 and $25 \mu \mathrm{M}$ reduced the 15 -min uptake of $\left[{ }^{125} \mathrm{I}\right] \mathrm{T}_{4}$ by $30 \%$ and $35 \%$, respectively, indicating that receptor-mediated endocytosis is involved in the uptake process. That the uptake of $\left[{ }^{125} \mathrm{I}\right] \mathrm{T}_{4}$ was dependent on the cellular energy status was indicated by the experiments with oligomycin $(10$ $\mu \mathrm{M})$, a compound that reduced $\mathrm{T}_{4}$ uptake by around $50 \%$. Finally, after $\mathrm{Na}^{+}$loading of the cells with monensin $(10 \mu \mathrm{M})$ or reduction of the $\mathrm{Na}^{+}$gradient by replacing the $\mathrm{Na}^{+}$in the buffer by $\mathrm{K}^{+},\left[{ }^{125} \mathrm{I}\right] \mathrm{T}_{4}$ uptake was reduced by $40 \%$, indicating that the uptake process is at least partly dependent on the $\mathrm{Na}^{+}$gradient. In addition, the experiments with the aromatic amino acids indicate that part of the $\left[{ }^{125} \mathrm{I}\right] \mathrm{T}_{4}$ uptake into pituitary cells might occur through the system $L$ and system $\mathrm{T}$ amino acid transporters, which are both $\mathrm{Na}^{+}$independent.

Surprisingly, all of these effects were similar to the effects on the uptake of $\left.{ }^{[25} \mathrm{I}\right] \mathrm{T}_{3}$ by pituitary cells. The same concentrations of MDC $(25 \mu \mathrm{M})$, oligomycin $(10 \mu \mathrm{M})$, and monensin $(10 \mu \mathrm{M})$ reduced $\mathrm{T}_{3}$ uptake by $26 \%, 68 \%$, and $37 \%$, respec- 
tively (9). Also, the effects of L-Phe, L-Tyr, and L-Trp on the uptake of $\left[{ }^{125} \mathrm{I}\right] \mathrm{T}_{3}$ described in the present study were similar to those on ${ }^{125} \mathrm{ITT}_{4}$ uptake. Together, these results suggest that the putative iodothyronine-transporting membrane protein may transport both $T_{3}$ and $T_{4}$ across the plasma membrane of pituitary cells. This is different from the situation in liver, where separate carriers presumably are involved in $\mathrm{T}_{3}$ and $\mathrm{T}_{4}$ uptake $(10)$

Finally, by expressing data on the $15-$ min uptake of $\left[{ }^{125} \mathrm{I}\right]$ $\mathrm{T}_{4}$ and $\left.{ }^{125} \mathrm{I}\right] \mathrm{T}_{3}$ per $\mathrm{pM}$ free hormone, it was found that the rates of $T_{3}$ and $T_{4}$ uptake were very similar. Moreover, the simultaneous addition of unlabeled $T_{4}$ or $T_{3}$ reduced the uptake of $\left[{ }^{125} \mathrm{IT}_{4}\right.$ to roughly the same extent; vice versa, the uptake of $\left[{ }^{125} \mathrm{I}\right] \mathrm{T}_{3}$ was reduced by about $50 \%$ by unlabeled $\mathrm{T}_{4}$ and $\mathrm{T}_{3}$. In agreement with earlier findings in rat glial cells in primary culture (12) and in pituitary tumor cells (8), our results are consistent with the view that $T_{3}$ and $T_{4}$ share a common carrier in the anterior pituitary.

In conclusion, the present results indicate that $\mathrm{T}_{4}$ is transported into cultured anterior pituitary cells by a carriermediated mechanism that is dependent on the cellular energy status and partly on the $\mathrm{Na}^{+}$gradient. Furthermore, the present results in combination with our previous data on ${ }^{125} \mathrm{IJT}_{3}$ uptake are consistent with the possibility that $\mathrm{T}_{3}$ and $\mathrm{T}_{4}$ share the same transporter in the anterior pituitary gland. Experiments to investigate whether adaptation of this transport system plays a role in the suppression of TSH secretion during starvation and nonthyroidal illness are in progress.

\section{Acknowledgments}

We thank Dr. L. J. Hofland for valuable discussions, and Mr. H. van Toor and Ms. A. M. P. Tempelaars for skilled technical assistance

\section{References}

1. Silva JE, Dick TE, Larsen PR 1978 The contribution of local tissue thyroxine monodeiodination to the nuclear 3,5,3'-triiodothyronine in pituitary, liver, and kidney of euthyroid rats. Endocrinology 103:1196-1207

2. Van Doorn J, Van der Heide D, Roelfsema F 1983 Sources and quantity of $3,5,3^{\prime}$-triiodothyronine in several tissues of the rat. J Clin Invest 72:1778-1792

3. St Germain DL, Galton VA 1985 Comparative study of pituitarythyroid hormone economy in fasting and hypothyroid rats. J Clin Invest 75:679-688

4. Rondeel JMM, Heide R, De Greef WJ, Van Toor $H$, Van Haasteren GAC, Klootwijk W, Visser TJ 1992 Effect of starvation and subsequent refeeding on thyroid function and release of hypothalamic thyrotropin-releasing hormone. Neuroendocrinology 56:348-353

5. Blake NG, Eckland DJA, Foster OJF, Lightman SL 1991 Inhibition of hypothalamic thyrotropin releasing hormone messenger ribonucleic acid during food deprivation. Endocrinology 129:2714-2718

6. Horiuchi R, Cheng S-Y, Willingham M, Pastan I 1982 Inhibition of the nuclear entry of 3,3',5-triiodo-L-thyronine by monodansylcadaverine in $\mathrm{GH}_{3}$ cells. J Biol Chem 257:3139-3144

7. Halpern J, Hinkle PM 1982 Evidence for an active step in thyroid hormone transport to nuclei: drug inhibition of $\mathrm{L}^{-125} \mathrm{I}$-triiodothyronine binding to nuclear receptors in rat pituitary tumor cells. Endocrinology 110:1070-1072

8. Yan Z, Hinkle PM 1993 Saturable, stereospecific transport of 3,5,3' triiodo- $\mathrm{L}$-thyronine and $\mathrm{L}$-thyroxine into $\mathrm{GH}_{4} \mathrm{C}_{1}$ pituitary cells. J Biol Chem 268:20179-20184

9. Everts ME, Docter R, Van Buuren JCJ, van Koetsveld PM, Hof- land LJ, de Jong M, Krenning EP, Hennemann G 1993 Evidence for carrier-mediated uptake of triiodothyronine in cultured anterior pituitary cells of euthyroid rats. Endocrinology 132:1278-1285

10. Krenning EP, Docter R, Bernard HF, Visser TJ, Hennemann G 1981 Characteristics of active transport of thyroid hormone into rat hepatocytes. Biochim Biophys Acta 676:314-320

11. Riley WW jr Eales JG 1993 Characterization of L-thyroxine transport into hepatocytes isolated from juvenile rainbow trout (Oncorhynchus mykiss). Gen Comp Endocrinol 90:31-42

12. Francon J, Chantoux F, Blondeau J-P 1989 Carrier-mediated transport of thyroid hormones into rat glial cells in primary culture J Neurochem 53:1456-1463

13. Lakshmanan M, Goncalves E, Lessly G, Foti D, Robbins J 1990 The transport of thyroxine into mouse neuroblastoma cells, NB41A3: the effect of $L$-system amino acids. Endocrinology 126:3245-3250

14. Blondeau J-P, Beslin A, Chantoux F, Francon J 1993 Triiodothyronine is a high-affinity inhibitor of amino acid transport system $L_{1}$ in cultured astrocytes. J Neurochem 60:1407-1413

15. Zhou Y, Samson M, Osty J, Francon J, Blondeau J-P 1990 Evidence for a close link between the thyroid hormone transport system and the amino acid transport system $\mathrm{T}$ in erythrocytes. J Biol Chem 265:17000-17004

16. Christensen HN 1990 Role of amino acid transport and countertransport in nutrition and metabolism. Physiol Rev 70:43-77

17. Oosterom R, Verleun T, Lamberts SWJ 1983 Basal and dopamineinhibited prolactin secretion by anterior pituitary cells: effects of culture conditions. Mol Cell Endocrinol 29:197-212

18. Oosterom R, Verleun T, Zuyderwijk J, Lamberts SWJ 1983 Growth hormone secretion by cultured rat anterior pituitary cells. Effects of culture conditions and dexamethasone. Endocrinology 113:735-741

19. Simpson P, McGrath A, Savion S 1982 Myocyte hypertrophy in neonatal heart cultures and its regulation by serum and by catecholamines. Circ Res 51:787-801

20. Webster J, Ham J, Bevan JS, ten Horn CD, Scanlon MF 1991 Preliminary characterization of growth factors secreted by human pituitary tumors. J Clin Endocrinol Metab 72:687-692

21. Arzt E, Buric R, Stelzer G, Stalla J, Sauer J, Renner U, Stalla GK 1993 Interleukin involvement in anterior pituitary cell growth regulation. Endocrinology 132:459-467

22. Docter $R$, Krenning EP, Bernard HF, Visser TJ, Hennemann G 1988 Inhibition of uptake of thyroid hormone into rat hepatocytes by preincubation with $N$-bromoacetyl-3,3',5-triiodothyronine. Endocrinology 123:1520-1525

23. Rutgers M, Heusdens FA, Visser TJ 1989 Metabolism of triiodothyroacetic acid $\left(\mathrm{TA}_{3}\right)$ in rat liver. I. Deiodination of $\mathrm{TA}_{3}$ and $\mathrm{TA}_{3}$ sulfate by microsomes. Endocrinology 125:424-432

24. Sterling K, Brenner MA 1966 Free thyroxine in human serum: simplified measurement with the aid of magnesium precipitation. J Clin Invest 45:153-163

25. Hofland LJ, van Koetsveld PM, Lamberts SWJ 1990 Percoll density gradient centrifugation of rat pituitary tumor cells: a study of functional heterogeneity within and between tumors with respect to growth rates, prolactin production and responsiveness to the somatostatin analog SMS 201-995. Eur J Cancer 26:37-44

26. Downs TR, Wilfinger WW 1983 Fluorimetric quantification of DNA in cells and tissues. Anal Biochem 131:538-547

27. Docter R, Krenning EP, Bernard HF, Hennemann G 1987 Active transport of iodothyronines into human cultured fibroblasts. J Clin Endocrinol Metab 65:624-628

28. Silva JE, Larsen PR 1977 Pituitary nuclear 3,5,3'-triiodothyronine and thyrotropin secretion: an explanation for the effect of thyroxine. Science 192:617-620

29. Obregon MJ, Pascual A, Mallol J, Morreale de Escobar G, Escobar del Rey F 1980 Evidence against a major role of L-thyroxine at the pituitary level: studies in rats treated with iopanoic acid (telepaque) Endocrinology 106:1827-1836

30. Emerson CH, Lew R, Braverman LE, DeVito WJ 1989 Serum thyrotropin concentrations are more highly correlated with serum triiodothyronine concentrations than with serum thyroxine concentrations in thyroid hormone-infused thyroidectomized rats. Endo- 
crinology 124:2415-2418

31. Abend SL, Fang SL, Alex S, Braverman LE, Leonard JL 1991 Rapid alteration in circulating free thyroxine modulates type II 5 'deiodinase and basal thyrotropin secretion in the rat. J Clin Invest 88:898-903

32. Pontecorvi A, Robbins J 1989 The plasma membrane and thyroid hormone entry into cells. Trends Endocrinol Metabolism 1:90-94

33. Docter R, Krenning EP 1990 Role of cellular transport systems in the regulation of thyroid hormone bioactivity. In: Greer MA (ed) The Thyroid Gland. Raven Press, New York, pp 233-254

34. Visser TJ, Kaplan MM, Leonard JL, Larsen PR 1983 Evidence for two pathways of iodothyronine 5 '-deiodination in rat pituitary that differ in kinetics, propylthiouracil sensitivity and response to hypothyroidism. J Clin Invest 71:992-1002

35. Koenig RJ, Leonard JL, Senator D, Rappaport N, Watson AY, Larsen PR 1984 Regulation of thyroxine 5 -deiodinase activity by $3,5,3^{\prime}$-triiodothyronine in cultured rat anterior pituitary cells. Endocrinology 115:324-329

36. Krenning EP, Docter R, Bernard HF, Visser T], Hennemann G 1979 The essential role of albumin in the active transport of thyroid hormones into primary cultured rat hepatocytes. FEBS Lett 107:227230 